\title{
EVA and the Impact of the Macroeconomic Variables: Evidence from the Jordanian Manufacturing Companies
}

\author{
Imad Zeyad Ramadan \\ Full Prof., Department of Finance, \\ Applied Science Privet University, P.O. Box 166, Amman, Jordan \\ E-mail: E-mail: i_ramadan@asu.edu.jo
}

Received: Nov. 5, $2015 \quad$ Accepted: Dec. 9, $2015 \quad$ Published: June 1, 2016

doi:10.5296/ajfa.v8i1.8614 URL: http://dx.doi.org/10.5296/ajfa.v8i1.8614

\begin{abstract}
This study aimed at examining the effect of macroeconomic variables on the performance of Jordanian manufacturing companies listed in Amman Stock Exchange expressed by EVA using unbalanced panel data pooled ordinary least square (OLS) regression model of all 77th Jordanian manufacturing companies listed at ASE for the period 2000-2014 resulting in 1085 firm-year observations connecting firm level and time series data set. This study has revealed that interest rate has statistically significant inverse effect on the performance of the Jordanian manufacturing companies $(\beta=-0.064$, $p$-value $<0.01)$. The results of this study have also revealed that Inflation $(\beta=0.0945, p$-value $<0.05)$ and Government expenditure $\operatorname{ratio}(\beta=0.0734, p$-value $<0.05)$ have a statistically significant positive effect on the performance of the Jordanian manufacturing companies at the significance level $<0.05$.Also, Gross domestic product $(\beta=0.00395$, $p$-value $<0.10)$ affects the performance of the Jordanian manufacturing companies at the significance level $<0.10$, and finally, the study has revealed that Money supply and the labor force indicator have no statistically significant effect on the performance of the Jordanian manufacturing companies. Basically, and depending on the results of this study, we can conclude that Economic Value Add (EVA) of the Jordanian manufacturing companies, as a proxy of the performance, is a function of Inflation, Interest rate, Government expenditure ratio and Gross domestic product.
\end{abstract}

Keywords: EVA; Macroeconomic variables; Jordan 


\section{Introduction}

In light of the significant changes and developments in recent economic aspects witnessed on the global level, financial accounting performance measurement systems -which basically depend on profitability - become incapable to perform proper performance measurement of the facility. This incapability encouraged the emergence of modern standards to measure the financial performance of the companies, which depend essentially on the creation of Firm's Value but not on accounting profit which has recently faced many criticisms and a lot of controversy. It is known that the interests of investors are not affected by the profitability of the company only, but are also affected by the changes associated with the market value of the company, what in turns formed a pressure that prompted companies to adopt appropriate measures that enable them to measure and determine the actual realizable value; of which, the most important and most famous was Economic Value Added (EVA).

Economic Value Added EVA can be defined as the difference between the value of company's inputs and outputs (Booth, 1998) during the company's activity, so whenever the value of the company's revenue is greater than the cost of purchasing inputs of company's activities, the company is working to create value. According to (Lieberman and Balasubramania, 2007) EVA concept differs from one person to another depending on the nature of such person, for example, for the consumer EVA is the production of goods or the provision of services continuously, but for the staff EVA means a great deal of respect in dealing, participation in decision-making, continuous training and lucrative rewards, while for the investors EVA means continuous High returns on capital which should include a high revenue growth and large profit margins and this can be achieved only if the company achieves a Value continuously. These various value-added concepts impose the measurement of achieving the goals of the company through value-added instead of the traditional view of short-term profits.

The traditional notion of the function of managers lies in their continuous quest to achieve growth in the wealth of the owners of the company and growth in return on assets, but modern managers have become aware that the new target for the company must be creating value to stakeholders regardless whether stakeholders have financial claims against the company or not, and thus, managers discovered that traditional measures of corporate performance should not be the main objective to be achieved, because these traditional measures are essentially considered as indicators to achieve the main goal of adding as much as possible economic value for the company.

The traditional accounting methods used in assessing the financial situation of the company, which rely on accounting profits (Return on Assets (ROA), Return on Equity (ROE), Earnings per share (EPS), Cash flow from operations (CFO) have faced several criticisms because they depend on estimation, as they are also affected by the used accounting methods, where the rate of accounting return has always been criticized for its inability to measure the economic profit (Fisher \& McGowan, 1983). Financial accounting reports have also faced several criticisms because of their low quality and lack of coherence and consistency in information-rich environment, so there has almost become a general consensus that 
traditional methods must be reviewed to overcome their shortcomings (Mashayekhi and Bahavarnia, 2007)

There became an urgent need to provide more accurate tools by relying on various standard methods such as: Value Based Management (VBM)) which provides awareness of a high degree of value of shares; also Cash Value Added (CVA) and (Economic Value Added (EVA) which have been developed by Stern Stewart \& Co. in 1989. These methods are all working to provide more accurate standardized methods as compared to inaccurate traditional ways of accounting.

Relying on accounting thought that considers profit as the sole criterion upon which performance measurement and evaluation depend on, and restricting financial reports to meet the needs of investors, have led to focus the company's efforts towards maximizing the profitability in the short term, as the generally accepted performance measures have become ineffective because they focus on results without addressing their causes; as such measures are almost away from value achieving activities.

The importance of this study stems from identifying the concept of Economic Value Added (EVA) as a new measure for corporate performance. The study problem stems from the unclarity of the extent to which Economic Value Added (EVA) of Jordanian manufacturing companies listed in Amman Stock Exchange is affected by macroeconomic variables whereas studies that addressed Economic Value Added (EVA) have focused on the internal factors of the company and the extent to which Economic Value Added (EVA) is affected by such factors without addressing macroeconomic variables.

\section{Literature review}

Previous studies have included a lot of discussion and controversy over the definition of the concept of value, the concept of created value or value-added, and the reason is that many researchers have explicitly declared that value added equals ordinary shareholders returns, which necessarily means that value created by a company belongs only to ordinary shareholders, and this idea stems mainly from the idea that the increase in the Firm's Value is achieved through maximizing short-term profits of shareholders.

It is no secret that the Firm's Value is affected by several factors such as the financial risk of the company (Bartram, 2000) the resources available to the company (Moran and Ghoshal, 1997) organizational capacity of the company (Ghashal, Hahn and Moran, 1997) intangible assets (Bounfour, 2000) as well as the classical accounting variables, which include ROE, structure of assets, the structure of capital, debt ratio, growth opportunities (Pariente, 2000) as well as acquisitions and capital allocation improvement.

Many studies (Fama and French, (2007); Martin, (2007); Glushkov, (2007)) have stated that there was a statistically significant relationship between the Economic Added Value of the company and each of sales growth, assets growth and in retained earnings growth. But the base of created value lies in keeping the profitability higher than the cost of equity. 
Pilot studies that examined the strength of the relationship between Market value or Market return and EVA comparing between Market return and traditional measures of income such as O'Byrne, (1996) have concluded that EVA, and unlike traditional measures of income or profits, are systematically linked with market value of the company. Therefore, EVA has a greater ability to predict the market value more than other measures. Uyemura, Kantor and Pettit, (1996) study has confirmed this result, however, Biddle, Bowen and Wallace, (1997) failed to reach evidence that strongly link EVA with Earnings and Firm's Value as it is the case in Stern Stewart, (2000).

Chen and Dodd, (1997) have concluded that EVA offers information more than traditional measures about stock return association, but EVA should be resolved once and for all rather than traditional measures, since these traditional measures such as ROA, E / P have incremental value in monitoring the firm's performance, as they have also concluded that there were no statistically significant differences between EVA and RI scale with Stock return.

Imoughela (2014) has carried out a study aiming at examining the effect of monetary policies on the performance of the Nigerian manufacturing companies during the period 1986-2012. The study concluded that there were a positive statistically significant relationship between the exchange rate, Foreign exchange reserves and interest rates on the growth of industrial sector. Also, the study has concluded the presence of a statistically significant effect of monetary policies on the performance of the industrial sector.

Dior (2013) has examined the effect of macroeconomic variables on the productivity of the industrial sector in Niger during the period 1975-2011. The study concluded that there was a statistically significant effect for Credit of the manufacturing sector and Foreign direct investment on the productivity of the industrial sector, while Money Supply did not have a significant impact on the productivity of the industrial sector.

Eze, Onyekachi and Okiji (2013) aimed at identifying the effect of Fiscal Policy on the performance of the industrial sector. The study concluded that there was statistically significant negative effect for Government Tax on industrial companies, while the Government Expenditure had had a positive impact on the industrial sector, also the results have confirmed the effect of the Fiscal Policy on the industrial sector.

Charles (2012) has examined the effect of Monetary Policy on the industrial sector in Nigeria and the study concluded that there were a statistically significant positive impact for Money Supply on the performance of the industrial sector, while there was a statistically significant negative impact for each of (inflation, tax and exchange rate) on the performance of industrial companies.

Tkalec and Vizek (2009) aimed to study the effect of macroeconomic variables on the productivity of industrial companies in Croatia. The study concluded that High-tech industries were elastic for change in Investment, foreign demand and fiscal policy and the impact of the Fiscal policy was significant on the performance of industrial companies in Croatia. The study also found that the performance of Low-tech industrial companies 
increases with the decline of Exchange rate, while the performance of industrial companies classified as medium and high technological companies declines depending on the decline in Exchange rate.

Tahma Siew, (1997) concluded that while the productivity of industrial companies in Malaysia is positively affected by Direct Investment, the productivity of the industrial sector is adversely affected by Capital Intensity.

Ray (1997) found a statistically significant positive impact for each of Urbaization and higher capital-labour ratio on the productivity of Indian companies.

\section{Methodology}

\subsection{Data}

The study utilized econometric analysis using unbalanced panel data pooled ordinary least square (OLS) regression model of all 77th Jordanian manufacturing companies listed at ASE for the period 2000-2014 resulting in 1085 firm-year observations connecting firm level and time series data set. The needed financial and economic data to test the impact of the macroeconomic variables on the Jordanian manufacturing economics value added were derived from the ASE website, Jordanian Department of Statistics website and the Central Bank of Jordan website. Following Odior (2013) and Omojimite (2012), macroeconomic variables were expressed as: interest rates (IN_R), inflation (INF), gross domestic product (GDP), labor force (LA_F), government expenditure ratio (G_EX) and money supply (MO_S).

\subsection{The Model}

Base on the above, EVA in this study, can be seen as a function of the macroeconomic variable as follows:

$$
E V A_{i t}=f\left(M E V_{i t}\right)
$$

Where, $E V A_{i t}$ is the economic value added for the $i^{\text {th }}$ company during the $t^{\text {th }}$ period. $M E V$ is the macroeconomic variables supposed to affect the $i^{t h}$ company in the $t^{t h}$ period.

The mathematical model for this study, based on equation (1) can be formatted as:

$$
\begin{gathered}
E V A_{i t}=\alpha_{0}+\beta_{1} I N_{-} R_{t}+\beta_{2} I N F_{t}+\beta_{3} G D P_{t}+\beta_{4} L A_{-} F_{t}+\beta_{5} G_{-} E X_{t}+\beta_{6} M O_{-} S_{t} \\
+\varepsilon
\end{gathered}
$$

Where $E V A_{i t}$ is the economic value added for the $i^{t h}$ cross-sectional company for the $t^{\text {th }}$ period, as $\mathrm{i}=1,2,3, \ldots, 77, \mathrm{t}=1,2,3, \ldots, 15 ; \alpha$ is the constant of the regression model; $\beta^{\prime s}$ unknown parameters in the regression model to be estimated; IN_R is the interest rate, INF is the inflation rate, GDP is the gross domestic product, LA_F is the labor force indicator, G_EX is the government expenditure ratio and MO_S is the money supply. Thus, the macroeconomic factors; and $\varepsilon$ is the random error.

Two variables that the previous studies have found to be significantly affecting the economic value added have been added as control variables to remove their effects from the equation. 


\section{Macrothink}

Asian Journal of Finance \& Accounting

ISSN 1946-052X 2016, Vol. 8, No. 1

Firms size (SIZ) is expressed as the natural logarithm of the total assets and firms' profitability (ROA) is expressed as the return on the assets. Thus mathematical model in equation 2 can be reformed to include the two control variables as follow:

$$
\begin{aligned}
E V A_{i t}=\alpha_{0} & +\beta_{1} I N_{-} R_{t}+\beta_{2} I N F_{t}+\beta_{3} G D P_{t}+\beta_{4} L A_{-} F_{t}+\beta_{5} G_{-} E X_{t}+\beta_{6} M O_{-} S_{t}+\beta_{7} S I Z_{i t} \\
& +\beta_{8} R O A_{i t}+\varepsilon
\end{aligned}
$$

EVA value will be calculated for each of the companies within the sample through the following equation:

Total Capital Deployed $=$ Working Capital + Net fixed assets

Cost of Capital $=$ Total Capital Deployed $\times$ WACC

$$
\text { EVA }=\text { Net Operating Profit after Tax - Cost of Capital }
$$

\section{Results and Discussions}

\subsection{Correlation analysis}

Data in Table 1 shows the results of correlation analysis between macroeconomic variables. The results indicate in the table that the correlation coefficients between macroeconomic variables, the independent variables in the study sample, were generally low, where the results have showed no strong correlation between the independent variables transforms that

\begin{tabular}{|c|c|c|c|c|c|c|}
\hline \multicolumn{7}{|c|}{ Correlation Analysis between the variables of interest } \\
\hline & IN_R & INF & GDP & LA_F & G_EX & MO_S \\
\hline IN_R & 1 & & & & & \\
\hline INF & 0.3339 & 1 & & & & \\
\hline GDP & 0.5310 & 0.1860 & 1 & & & \\
\hline LA_F & -0.0912 & -0.3880 & 0.2037 & 1 & & \\
\hline G_EX & -0.0224 & 0.1258 & -0.4995 & -0.1485 & 1 & \\
\hline MO_S & -0.5502 & -0.3454 & -0.1667 & -0.0849 & 0.3262 & 1 \\
\hline
\end{tabular}
have been used as independent variables in the study sample.

Table 1.

IN_R is the interest rate,INF is the inflation rate, GDP is the gross domestic product, LA_F is the labor force indicator, G_EX is the government expenditure ratio and $\mathrm{MO} \_\mathrm{S}$ is the money supply

Source: Calculations from SPSS by the author, 2015.

The results appear in Table 1 that there is a negative correlation between interest rate (IN_R) and LA_F, G_EX and MO_S, and an inverse correlation between inflation (INF) and LA_F 


\section{Macrothink}

and MO_S. Also the results show negative correlation between gross domestic product (GDP) and G_EX and MO_S, and an inverse correlation between labor force indicator (LA_F) and MO_S, while the other interactions were positively correlated.

\subsection{Regression analysis}

Table (2) shows the results that have been obtained by applying the mathematical model for the study using unbalanced panel data pooled ordinary least square (OLS) regression model.

Table 2. Regression analysis results

\begin{tabular}{|c|c|c|}
\hline Variables & $\beta$ & t-value \\
\hline INF & $0.0945 * *$ & 1.970 \\
\hline IN_R & $-0.0640 *$ & -2.616 \\
\hline GDP & $0.00395 * * *$ & 1.696 \\
\hline LA_F & 0.0279 & 1.440 \\
\hline G_EX & $0.0734 * *$ & 2.115 \\
\hline MO_S & 1.874 & 1.305 \\
\hline SIZ & $0.021 * *$ & 2.186 \\
\hline ROA & 1.912 & \\
\hline N. & 1085 & \\
\hline Adj. R-square & 0.233 & \\
\hline F-Statistics & 0.00 & \\
\hline Durbin-Watson & 2.013 & \\
\hline \multicolumn{3}{|c|}{$\begin{array}{l}*, * * \text { and } * * * \text { indicate level of significance at } 1 \%, 5 \% \text { and } 10 \% \text {, } \\
\text { respectively; IN_R is the interest rates,INF is the inflation rate, GDP is the } \\
\text { gross domestic product, LA_F is the labor force indicator, G_EX is the } \\
\text { government expenditure ratio and MO_S is the money supply. }\end{array}$} \\
\hline
\end{tabular}

Source: Calculations from SPSS by the author, 2015.

The table shows that the results of the regression coefficients of the Explanatory Variables were of statistical significance in Most of them, the results showed that the INF positively significantly affected the performance of the Jordanian manufacturing companies $(\beta=0.0945$, $\mathrm{p}<0.05)$. This is consistent with what was expected that the impact of inflation on companies' performance measured by EVA is significantly positive. 
The impact of IN_R is significantly negative on the Jordanian manufacturing companies $(\beta=$ $0.0641, p<0.01$ ). This result is consistent with what is expected, where that with the increase in funding costs the total cost of factors of production increases, which negatively affects the performance of the company. Also, the Table shows that the impact of GDP on EVA is positive and statistically significant $(\beta=0.00395, p<0.10)$, the table also shows that G_EX appeared to have a positive significant impact on the Jordanian manufacturing companies $(\beta=0.0734, p<0.05)$.

The results also show a positive insignificant effect of LA_F and MO_S on EVA ( $\beta=0.0279$, $\mathrm{p}>0.10)$ and $(\beta=1.874, \mathrm{p}>0.10)$ respectively.

\section{Summary and Conclusion}

Basically, depending on the results of this study, we can conclude: Firstly, the Economic Value Add (EVA) of the Jordanian manufacturing companies, as a proxy of the performance, is a function of Inflation, Interest rate, Government expenditure ratio and Gross domestic product. Secondly, Jordanian manufacturing companies have to develop their policies that aim to exploitation and utilization of variables that positively affect the EVA. Finally, government should design regulatory policies to enhance its efficiency in reducing inflation rates to ease the negative effects of inflation on the potential EVA of the companies.

\section{Acknowledgements}

The author is grateful to the Applied Science Private University, Amman, Jordan, for the financial support granted to this research project (Grant No. DRGS-2014-2015-209).

\section{References}

Biddle, G. C., Bowen, R. M., \& Wallace, J. S. (1997). Does EVA beat earnings? Evidence on associations with stock returns and firm values. Journal of Accounting and Economics, 24(3), 301-336. http://dx.doi.org/10.1016/S0165-4101(98)00010-X

Bounfour, A. (2000). Le valeurdynamique du capital immateriel (the dynamic nature of intangible capital), Revue Francaise de Gestion; 0 (130), September - October.

Bowman, C., \& Ambrosini, V. (2000). Value Creation versus Value Capture: Towards a Coherent Definition of Value in Strategy. British Journal of Management, 11(1), 1-15. http://dx.doi.org/10.1111/1467-8551.00147

Charles, A. N. B. (2012). Investigating the Performance of Monetary Policy on Manufacturing Sector in Nigeria. Arabian Journal of Business and Management Review, 2(1), $12-25$.

Chen, S., \& Dodd, J. L. (1997). Economic Value Added (EVATM): An empirical examination of a new corporate performance measure. Journal of Managerial Issues, 9(3), $318-333$. 
Eze, Onyekachi Richard and Ogiji, Festus O. (2013), Impact of Fiscal Policy on the Manufacturing Sector Output in Nigeria: An Error Correction Analysis. International Journal of Business and Management Review, 1(3), 35 - 55.

Fama, E. F., \& French, K. R. (2007). The anatomy of value and growth stock returns. Financial Analysts Journal, 63(6). Available at SSRN: http://ssrn.com/abstract=1071124.

Fisher, F.M., \& McGowan, J.J. (1983). On the misuse of accounting rate of returns to infer monopoly profits. American Economic Review, 73(1), 65-86.

Ghoshal, S., Hahn, M., \& Moran, P. (1997). Management competence, firm growth and economic progress; INSEAD Working Papers, 97/21/SM, February.

Glushkov, D. (2007). The importance of catering incentives: growth or profitability? Working Paper Series. Available at SSRN: http://ssrn.com/abstract=943439.

Imoughele, L. E. (2014). Empirical Investigation of the Impact of Monetary Policy on Manufacturing Sector Performance in Nigeria: 1989 to 2012. International Journal of Education and Research, 2(1), 1 -20.

Lieberman, M., \& Balasubramanian, N. (2007). Measuring Value Creation and Its Distribution Among Stakeholders of the Firm. Paper Presented at the Academy of Management Annual Meeting, 2005 and the Atlanta Competitive Advantage Conference in 2007. http://dx.doi.org/10.2139/ssrn.2382099

Martin, X. (2007). Inter-temporal persistence and mispricing of accruals and growth in long-term net operating assets: growth or accounting distortions? Working Paper Series, March. Available at SSRN: http://ssrn.com/abstract=975850.

Mashayekhi, B., Talebi, A., \& Bahavarnia, V. (2007). Eva versus earnings: evidence from Iran. International Journal of Accounting and Information Management, 18, (1).

Moran, P., \& Ghoshal, S. (1997). Value creation by firms; INSEAD Working Papers: 97/19/SM, February.

O'Byrne, S. F. (1996). EVA and market value. Journal of Applied Corporate Finance, 9(1), 116 - 125. http://dx.doi.org/10.1111/j.1745-6622.1996.tb00109.x

Odior, E.S. (2013). MACROECONOMIC Variables and the Productivity of the Manufacturing Sector in Nigeria: A static Analysis Approach. Journal of Emerging Issues in Economics, Finance and Banking (JEIEFB), 5, 362-380.

Omojimite, B. (2012). Institutions, Macroeconomic Policy and the Growth of the Agricultural Sector in Nigeria. Global Journal of Human Social Science, 12(1), 1-9.

Pariente, S. (2000). Rendementboursier, creation de valeuretdonneescomptables: une etude sur le marchefranchais (With English summary). Revue Finance ControleStrategie, 3(3), September. 
Ray, S. C. (1997). Regional Variation in Productivity Growth in Indian Manufacturing: A Nonparametric Analysis. Journal of Quantitative Economics, 13(1), 73-94.

Stern Stewart, \& Co. (2000). WWW home page. [Online] Available: http://www.sternstewart.com/index2.shtml.

Taham, Siew Yean. (1997). Determinants of Productivity Growth in the Malaysian Manufacturing Sector. ASEAN Economic Bulletin, 13(3), 333-343. http://dx.doi.org/10.1355/AE13-3D

Tkalec, M., \& Vizek, M. (2009). The Impact of Macroeconomic Policies on Manufacturing Production in Croatia. Privredna kretanja i ekonomska politika 121/2009.

Uyemura, D. G., Kantor, C. C., \& Pettit, J. M. (1996). EVA® for banks: Value creation, risk management, and profitability measurement. Journal of Applied Corporate Finance, 9(2), 94-113. http://dx.doi.org/10.1111/j.1745-6622.1996.tb00118.x 